\title{
The Traditional Games-Based Thematic Teaching Materials in Improving Students' Social Competence
}

\author{
Muh Ahadi ${ }^{1}$, Phil Ihwan Azhari ${ }^{2}$, Anita Yus ${ }^{3}$ \\ ${ }^{1}$ Student of Master's Degree of Primary Education, Universitas Negeri Medan \\ ${ }^{2,3}$ Lecturers of Master's Degree of Primary Education, Universitas Negeri Medan \\ Jl.Willem Iskandar Psr. V Medan Estate, Medan, Indonesia, 20221
}

Corresponding Author: Muh Ahadi

\begin{abstract}
The aims of this study were to produce the traditional games-based teaching materials that were suitable for use in thematic learning and to determine its effectiveness in improving students' social competence for the fourth grade students. The study applied the ADDIE developmental model. The results showed that: (1) a validation of design expert was $88 \%$ (excellent), a material expert regarding the language feasibility was $95.53 \%$ (excellent), a social studies expert was $84 \%$ (excellent), a science expert was 85.8 (excellent), (2) the students' responses on the traditional gamesbased teaching materials in the individual trial of 3 students were $81.66 \%$ (excellent), small group trial of 9 students were $87.77 \%$ (excellent), field trial of 17 students were $86.21 \%$ (excellent), and (3) there was an improvement of students' social competence after conducting the learning activity with the traditional games-based teaching materials. This has proven that traditional games-based teaching materials were very suitable for the use in thematic learning of the fourth grade students.
\end{abstract}

Keywords: Thematic Teaching Materials, Traditional Games, Social Competence

\section{INTRODUCTION}

The negative influence of globalization has an impact on the waning of the nation's cultural values as a guide for life (Nurhaidah \& Musa, 2015). Children who tend to continually use smartphones will feel cool enjoying game offerings compared to playing with their peers in the home environment (Putri, 2018). In traditional games, children achieve faster physical, intellectual, emotional and social development. Traditional games have high social and psychological values, have beneficial values on the physical-motor, intellectual, socio-economic, emotional and personality development of children (Latifah \& Sagala, 2015).

Traditional games are very rarely done by children nowadays. As we all know, games are the most effective means of interaction for children. Vygotsky's theory of learning (Trianto, 2009) proposes that to gain new knowledge, children need full interaction with other people. Reapplying traditional games is an educational alternative to optimize children's development. The results of several studies that have been conducted has shown that traditional games can improve various aspects of child development (Haris, 2016). Traditional games can improve character education and social competence in early childhood which includes religious values, honesty, tolerance, discipline, hard work, creative, independent, democratic, curiosity, love of the country, respect for achievement, friendly/communicative, love of peace, social care, and responsibility (Lestari, 2017).

The teaching materials used in the fourth grade of SD Negeri 060837 Medan are the thematic book packages of Grafindo 
Media Pratama Publisher. The results of the author's analysis of the thematic book Kupetik themed A Beautiful Togetherness with sub-themed A Cultural Diversity of My Nation; Togetherness in Diversity; and Gratitude for diversity, the themes had not been linked to the concept of local wisdom in the form of traditional games.

According to the author's analysis, the sub-material of the theme of a cultural diversity of my nation was very potential to be developed with the concept of local wisdom in the form of traditional games such as the Diversity of My Nation's Culture to become the Diversity of Traditional Games; Togetherness in Diversity is developed into Togetherness in Traditional Games; and Gratitude for Diversity is developed to become Gratitude for Diversity in Indonesian Traditional Games.

A social competence is very necessary when students enter peer groups. Several facts has shown that students with low social competence are generally disliked, ostracized, or ignored by their peers. Social competence can be trained, learned and developed in childhood, so that there are still opportunities to develop and improve it to contribute to the success of one's life (Thalib, 2010). Social competence is not an ability that individuals carry from birth but is obtained through the learning process, both learning from parents as the closest figure to children and learning from peers and the community. Ramdani, (1994) states that social competence is a skill that is acquired by individuals through the learning process, regarding ways to handle or carry out social relationships appropriately and well. Based on these opinions and research results, it was concluded that social competence was the ability to regulate thoughts, emotions and behavior to initiate and maintain relationships or interactions with the social environment effectively by considering social norms and interests as well as personal goals.

Traditional games are human activities that express emotions that are entertainment in a certain conceptual way and stick to local wisdom, namely norms and customs that have existed from generation to generation (Wahyu, 2015). Characteristics in traditional games are play and game. Traditional games are children's games made of simple materials according to cultural aspects of people's lives (Sukirman, 2008).

Based on the explanation aforementioned above, it is concluded that traditional games are a means to in still positive values as a therapeutic tool, solve social competency problems and release tension in children because in traditional games it can develop cognitive, psychomotor, affective and psychological aspects of children so that after playing children get pleasure, joy, and satisfaction.

The results of Mahardika's (2014) concluded that Javanese traditional games could improve children's social behavior. The results of Haris' (2016) concluded that the traditional games of Jamuran and Bathok Sluku could be developed as effective learning media; and the traditional games of Jamuran and Bathok Sluku as effective learning media to develop moral and language aspects of early childhood with a percentage of $80 \%$ of students learning completely. The results of Yus' and Thahir further study (2018) concluded that playing blocks can develop children's cognitive and creativity in Kindergarten.

\section{RESEARCH METHOD}

This was conducted in SD Negeri No. 060837 Medan in the Second Semester of the 2019/2020 Academic Year. This study applied the ADDIE research and development model in short for Analyze, Design, Development, Implementation, and Evaluation. The subject of the trial was the product users; fourth grade students of SD Negeri 060837 Medan. The Product development after testing required repetitions in the framework of formative evaluation obtained from the experts of learning design, material and the media as well. The data collection technique 
Muh Ahadi et.al. The traditional games-based thematic teaching materials in improving students' social competence

employed the questionnaires containing several aspects of assessment sheets and a critique or suggestion box to obtain data on the feasibility of traditional game-based teaching materials from the experts of learning material, design and media, teachers and fourth grade students as well.

\section{RESULTS AND DISCUSSION}

The results of the literature survey found that the teaching materials used by the teachers of SD Negeri No. 060837 Medan entitled "Tematik Kupetik of Grafindo Media Pratama Publisher". The results of the author's analysis of the thematic book Kupetik themed A Beautiful Togetherness with sub-themed A Cultural Diversity of My Nation; Togetherness in
Diversity; and Gratitude for diversity, the themes had not been linked to the concept of local wisdom in the form of traditional games.

The results of the needs analysis distributed to students obtained the following conclusions: (1) students already have a smartphone (100\%); (2) students use smartphones every day continuously $(88.23 \%)$; (3) requires or not smartphones in learning (100\%); (4) feeling that they enjoy serving games compared to playing with peers $(94.11 \%)$; (5) getting to know one of the traditional games $(100 \%) ;(6)$ often playing traditional games $(0 \%)$; (7) getting to know the benefits of traditional games (11.76\%); and teaching materials used are based on traditional games $(0 \%)$.

Table 1: The Data of Needs Analysis

\begin{tabular}{|c|l|c|c|c|c|}
\hline No & Type of Information & Answers & Frequency & & Total \\
\hline & & & Students & Percentage & \\
\hline 1. & Students already have a smartphone & Yes & 17 & $100 \%$ & 17 \\
\hline & & No & 0 & $0 \%$ & \\
\hline 2. & Students use smartphones every day continuously & Yes & 15 & $88.23 \%$ & 17 \\
\hline & & No & 2 & $11.76 \%$ & \\
\hline 3. & Requires or not smartphones in learning & Yes & 17 & $100 \%$ & 17 \\
\hline & & No & 0 & $0 \%$ & \\
\hline 4. & Feeling that they enjoy serving games compared to playing with peers & Yes & 16 & $94.11 \%$ & 17 \\
\hline & & No & 1 & $5.88 \%$ & \\
\hline 5. & Getting to know one of the traditional games & Yes & 17 & $100 \%$ & 17 \\
\hline & & No & 0 & $0 \%$ & \\
\hline 6. & Often playing traditional games & Yes & - & $0 \%$ & 17 \\
\hline & & No & 17 & $100 \%$ & \\
\hline 7. & Getting to know the benefits of traditional games & Yes & 2 & $11.76 \%$ & 17 \\
\hline & & No & 15 & $88.23 \%$ & \\
\hline 8. & Teaching materials used are based on traditional games & Yes & - & $0 \%$ & 17 \\
\hline & & No & 17 & $100 \%$ & \\
\hline
\end{tabular}

The results of the learning design expert assessment about the size of teaching materials, the cover design of teaching materials, and the content design of teaching materials were summarized in Figure 1.

Based on the figure aforementioned above, the results of all assessment components from the experts of media design was $88.8 \%$ in an excellent criteria. This means that the design of teaching materials based on traditional games for fourth grade elementary school students that were developed could meet the demands of learning needs and were feasible to continue for effectiveness testing in the field.

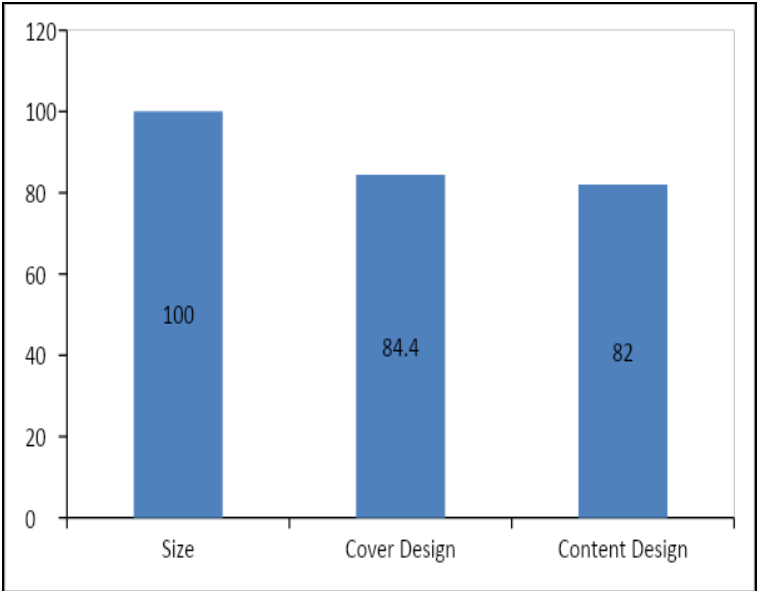

Fig.1: The Results of the Design Expert's Assessment on the Size, Cover Design, and Content Design of Teaching Materials in the $2^{\text {nd }}$ Meeting

The mean percentage of the material expert's assessment was shown in Figure 2. 
Muh Ahadi et.al. The traditional games-based thematic teaching materials in improving students' social competence

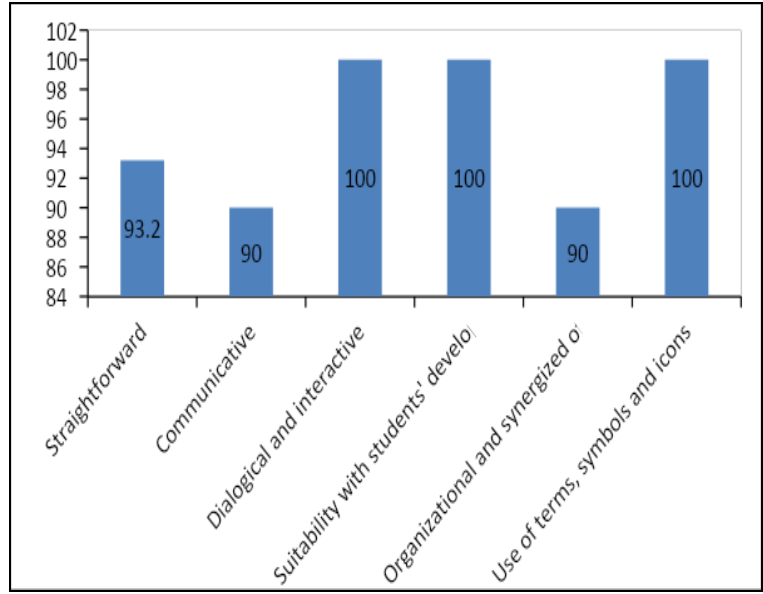

Fig. 2: The Results of the Material Expert's Assessment on Language Feasibility

Based on the figure above, the entire assessment of teaching materials on the feasibility of language obtained a mean score of $95.53 \%$ in an excellent category and very suitable for the use in the field.

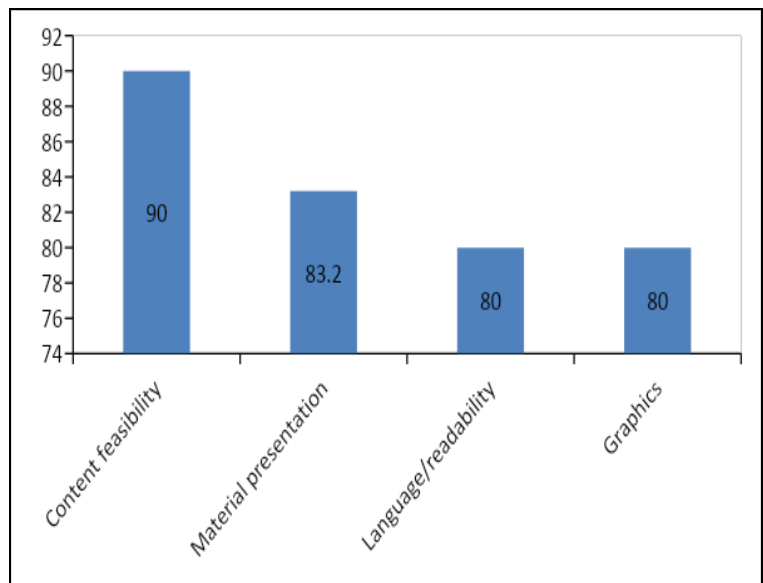

Fig. 3: The Mean Percentage of the Material Expert's Assessment in Historical Social Studies

Based on this assessment, the traditional games-based thematic teaching materials were included in an excellent category and very suitable for the use in the field with some improvements and did not need to be re-validated for the next meeting.
The mean percentage of the material expert's assessment in natural sciences was shown in Figure 4.

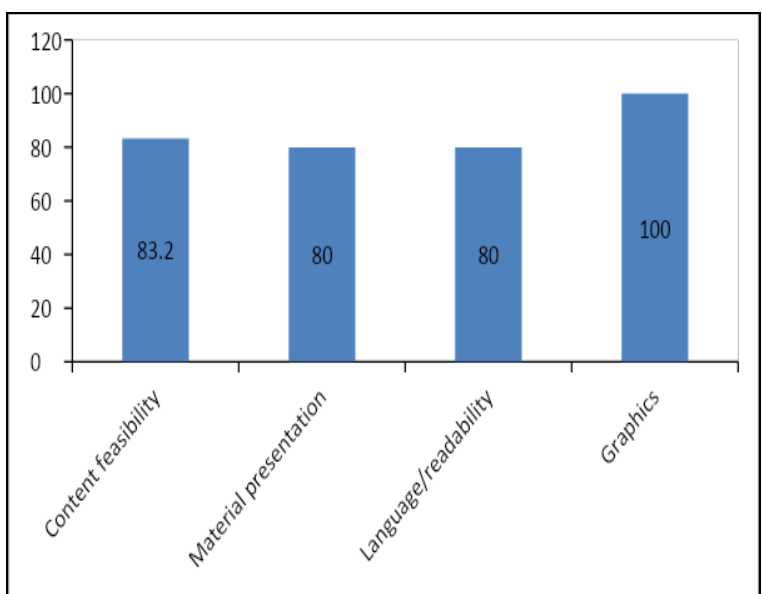

Fig. 4: The Mean Percentage of the Material Expert's Assessment in Natural Sciences

The assessment of each of the four aspects showed the percentage of each assessment; $83.2 \%$ in the aspect of content feasibility, the material presentation was $80 \%$, the linguistic aspect was $80 \%$ and the material expert's graphics gave an assessment with a score of $100 \%$. Based on the assessment, the traditional games-based thematic teaching materials were included in an excellent category.

Criticism and suggestions from the experts of natural science material stated that it was adequate, but it was very necessary to describe the relationship between traditional games and the right science concept in order to make the thematic teaching materials perfect based on traditional games so that they were suitable for the use in the field without revision and no need to re-validate further meeting.

Table 2: The Tendency Levels of Assessment of Traditional Games-based Thematic Teaching Materials in Individual Testing

\begin{tabular}{|c|c|l|c|}
\hline No. & \multicolumn{1}{|c|}{ Aspects } & Mean Score & Criteria \\
\hline 1. & The Quality of Learning Material & $83.80 \%$ & Excellent \\
\hline 2. & The Quality of Technical Display & $79.99 \% \leq X \leq 80 \%$ & Good \\
\hline Average & & $\mathbf{8 1 . 6 6 \%}$ & Excellent \\
\hline
\end{tabular}

Based on the table above, the tendency levels of assessment of traditional games-based thematic teaching materials in individual testing from the quality of learning material and the technical display showed the mean score obtained was $81.66 \%$ in an excellent criteria. 
Muh Ahadi et.al. The traditional games-based thematic teaching materials in improving students' social competence

Table 3: The Tendency Levels of Assessment of Traditional Games-based Thematic Teaching Materials in Small Group Testing

\begin{tabular}{|c|c|c|c|}
\hline No. & Aspects & Mean Score & Criteria \\
\hline 1. & The Quality of Learning Material & $87.61 \%$ & Excellent \\
\hline 2. & The Quality of Technical Display & $87.93 \% \leq X \leq 80 \%$ & Excellent \\
\hline Average & & $\mathbf{8 7 . 7 7 \%}$ & Excellent \\
\hline
\end{tabular}

Table 4: The Tendency Levels of Assessment of Traditional Games-based Thematic Teaching Materials in Field Testing

\begin{tabular}{|c|c|l|c|}
\hline No. & \multicolumn{1}{|c|}{ Aspects } & Mean Score & Criteria \\
\hline 1. & The Quality of Learning Material & $86.54 \%$ & Excellent \\
\hline 2. & The Quality of Technical Display & $85.88 \% \leq X \leq 80 \%$ & Excellent \\
\hline Average & & $\mathbf{8 6 . 2 1 \%}$ & Excellent \\
\hline
\end{tabular}

Based on the table above, the tendency levels of assessment of traditional games-based thematic teaching materials in small group testing from the quality of learning material and the technical display showed the mean score obtained was $87.77 \%$ in an excellent criteria.

Based on the table above, the tendency levels of assessment of traditional games-based thematic teaching materials in field testing from the quality of learning material and the technical display showed the mean score obtained was $86.21 \%$ in an excellent criteria.

The traditional games of the fourth grade students in SD Negeri No. 060837 Medan is a game that expresses emotions that are entertainment in nature with a certain concept and sticking to the norms and customs that have existed for generations. The types of games that are applied are (a) Marlayang-kite (b) Marjalengkat (c) Marpicek (d) Pat Ni Gaja, and (e) Batu Marsiada. Based on the results of the study conducted, these games provide opportunities for children to improve social competence.

The traditional games used as teaching materials are successful in improving the social competence of fourth grade students. The social competence in question is that it can bring children to be more courageous in expressing themselves, expressing every feeling or problem they are facing and at the same time finding adaptive solutions, so that they do not seek escape to other things that can actually harm themselves and others.

The increase in children's social competence is generated based on the characteristics of traditional games, namely having noble values and certain moral messages such as the values of togetherness, honesty, responsibility, generosity (if you experience defeat), drive for achievement, respect for others, intimacy, tolerance, active, creative, independence, concern for the surrounding environment, solidarity, sportivity, and obeying the rules. Traditional games have a flexible nature, that is, they can be played indoors or outdoors (although they are mostly played outdoors or in open fields) and the rules can be adjusted according to the agreement of the players; and traditional games provide emotional experiences that are born from physical contact and eye contact as well as communication between players which is useful for children's mental development.

Some of the uses and benefits in using thematic teaching materials based on traditional games are as follows: (1) the material is easy to understand because the concepts presented are planned to make it easier for students and systematic, (2) teaching materials provide opportunities for students to obtain competitive values, and entertainment, (3) learning is faster and more interesting so that it does not cause boredom because it is equipped with traditional games that train psychomotor development, cognitive, balance, communicative, so that it is beneficial for children's mental development, and (4) these traditional games-based thematic teaching materials can also be used as an alternative learning media in groups or individually.

The results of this study were in line with the results of previous research which concluded that traditional games as an effective learning medium can develop 
Muh Ahadi et.al. The traditional games-based thematic teaching materials in improving students' social competence

moral and language aspects of early childhood and can improve character education which includes religious values, honesty, tolerance, discipline, hard work, creative, independent, democratic, curiosity, loving the country, respect for achievement, friendly/communicative, peace-loving, social care, and responsibility. Teaching materials are assessed for their feasibility based on aspects of content, presentation, language, and graphics. The results of the validation of expert lecturers and student responses indicate that the product developed is in the category of fit for use.

The results of the assessment and suggestions given by the experts of design, language, social science and natural science materials on the traditional games-based thematic teaching materials developed in an excellent category.

Students' social behavior before using traditional games-based thematic teaching materials was $94.11 \%$ (16 out of 17 students who have smartphones) enjoying game offerings compared to playing with their peers in the home environment; $82.35 \%$ (14 of 17 students) often do not care who the people around them are, and $88.23 \%$ (15 of 17 students who have smartphones) showed that the inability of children to cooperate, adapt, interact, control themselves, empathize, obey the rules and not able to respect others. After using traditional games-based teaching materials, the students' social behavior changed about $88.23 \%$ of students feel being cool enjoying playing with their peers in the home environment compared to playing games with smartphones; $94.11 \%$ of them often care who people are around to play traditional games; and $100 \%$ of them are easy to work with, adapt, interact, control themselves, empathize, obey the rules and respect others.

The current results were in line with the results of research conducted by Iswinarti, (2015) concluded that traditional games had high social and psychological values, possessed beneficial values on children's physical-motor, intellectual, socio-economic, emotional and personality development.

\section{CONCLUSION}

The traditional games-based thematic teaching materials that had been developed effectively in improving students' social competence.

\section{REFERENCES}

1. Haris, I. 2016. The Use of Traditional Games as Learning Media for Early Childhood to Develop Moral and Language Aspects of Children. Journal of Widya Wacana, 11(1): 15-25.

2. Iswinarti. 2015. Therapeutic Values of Engklek Traditional Games in Elementary School-aged Children. Journal of Humanity, 6(1): 41-44.

3. Lestari, W. 2017. The Potential of Traditional Games in Developing Social Skills for Elementary School-aged Children. Multi-disciplinary National Seminar Journal of University of Asahan, The Program of PGSD. Faculty of Teaching and Education Nahdatul Ulama University, North Sumatera.

4. Mahardika, E.K. 2014. Increasing Children's Social Behavior Through Javanese Traditional Games. Journal of Early Childhood Education, 8(2): 257-268.

5. Nurhaidah, M., Musa, I. 2015. The Impact of Globalization on the Life of the Indonesian Nation. Journal of Pesona Dasar, 3(3): 1-14.

6. Putri, M. 2013. Play, Toys, and Games. Jakarta: PT Grasindo.

7. Ramdani, M. 1994. Decision Support Systems: A Structural Discourse of Idealization and Implementation of Decision Making Concepts. Bandung: PT. Youth Rosdakarya.

8. Sukirman, D. 2008. Javanese Traditional Games. Yogyakarta: Kepel Press.

9. Talib, S.B. 2010. Educational Psychology Based on Applicative Empirical Analysis. Jakarta: Kencana Media Group.

10. Trianto. 2009. Constructivist Oriented Innovative Learning Models. Jakarta: Prestasi Pustaka.

11. Wahyu. 2015. The Meaning of Local Wisdom in Natural Resources and Environmental Management in South Kalimantan (in Natural Resource 
Muh Ahadi et.al. The traditional games-based thematic teaching materials in improving students' social competence

Management and Community

Empowerment in a Cultural Perspective and

Local Wisdom). Article. Lambung Mangkurat University Press. Banjarmasin.

12. Yus, A. 2013. Playing as a Children's Need and Self-Development Strategy. Jurnal Ilmiah VISI P2TK PAUDNI 1. The Basic
Education of Universitas Negeri Medan, 8(2): 36-45.

How to cite this article: Ahadi M, Azhari PI, Yus A. The traditional games-based thematic teaching materials in improving students' social competence. International Journal of Research and Review. 2021; 8(1): 65-71. 